$149 / 1-93952$

RFP-4599

April 14, 1993
RFP-4599

April 14, 1993

\title{
HYDROGEN PEROXIDE SAFETY ISSUES
}

\author{
W. V. Conner
}

\section{E EERE ROCKY FLATS \\ Rocky Flats Plant \\ P. O. Box 464 \\ Golden, Colorado 80402-0464}




\section{DISCLAIMER}

This report was prepared as an account of work sponsored by an agency of the United States Government. Neither the United States Government nor any agency thereof, nor any of their employees, makes any warranty, expressed or implied, or assumes any legal liability or responsibility for the accuracy, completeness, or usefulness of any information, apparatus, product, or process disclosed, or represents that its use would not infringe privately owned rights. Reference herein to any specific commercial product, process, or service by trade name, trademark, manufacturer, or otherwise, does not necessarily constitute or imply its endorsement, recommendation, or favoring by the United States Government or any agency thereof. The view and opinions of authors expressed herein do not necessarily state or reflect those of the United States Government or any agency thereof.

This report has been reproduced directly from the best available copy.

Available to DOE and DOE contractors from the Office of Scientific and Technical Information. P. O. Box 62, Oak Ridge, TN 37831; prices available from (615) 576-8401, FTS 626-8401.

Available to the public from the National Technical Information Service, U.S. Department of Commerce, 5285 Port Royal Rd., Springfield, VA 22161. 


\title{
HYDROGEN PEROXIDE SAFETY ISSUES
}

\author{
W. V. Conner
}

\section{SUBJECT DESCRIPTORS}

Decomposition

Hydrogen Peroxide

Safety

EG\&G ROCKY FLATS, INC.

ROCKY FLATS PLANT

P. O. BOX 464

GOLDEN, COLORADO 80402-0464

PREPARED UNDER CONTRACT DE-AC04-90DE62349

FOR THE

ALBUQUERQUE OPERATIONS OFFICE

U.S. DEPARTMENT OF ENERGY 


\section{CONTENTS}

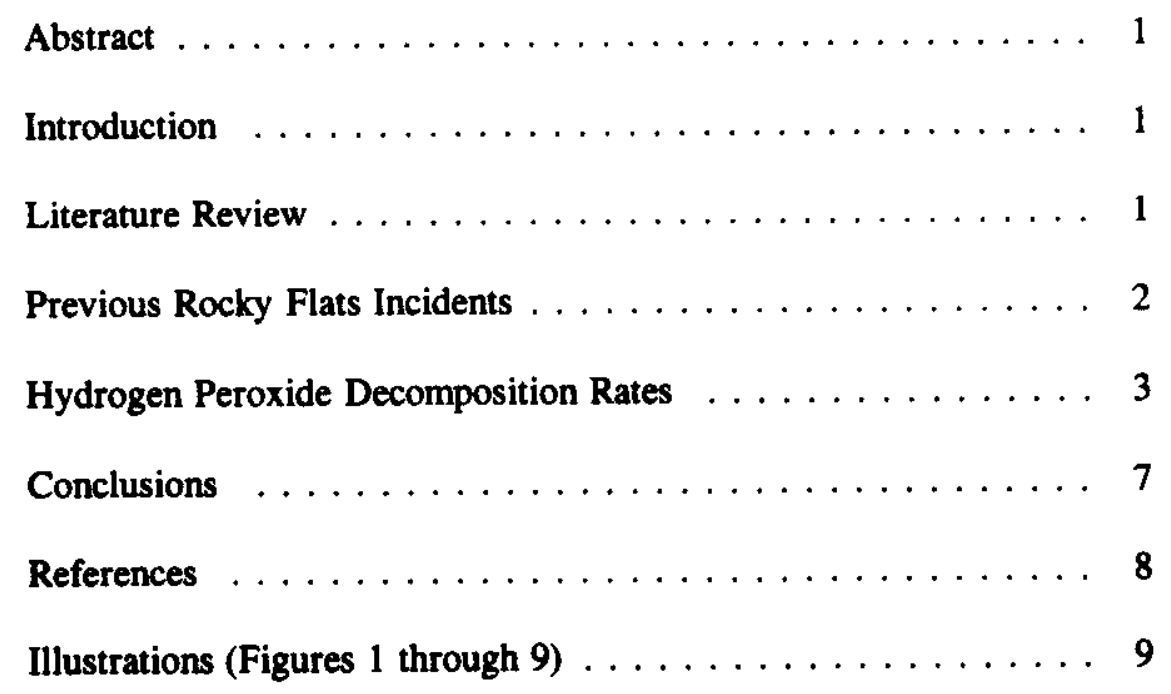




\title{
HYDROGEN PEROXIDE SAFETY ISSUES
}

\author{
W. V. Conner
}

\section{ABSTRACT}

A literature survey was conducted to review the safety issues involved in handling hydrogen peroxide solutions. Most of the information found in the literature is not directly applicable to conditions at the Rocky Flats Plant, but one report describes experimental work conducted previously at Rocky Flats to determine decomposition reaction-rate constants for hydrogen peroxide solutions. Data from this report were used to calculate decomposition half-life times for hydrogen peroxide in solutions containing several decomposition catalysts. The information developed from this survey indicates that hydrogen peroxide will undergo both homogeneous and heterogeneous decomposition. The rate of decomposition is affected by temperature and the presence of catalytic agents. Decomposition of hydrogen peroxide is catalyzed by alkalies, strong acids, platinum group and transition metals, and dissolved salts of transition metals. Depending upon conditions, the consequence of a hydrogen peroxide decomposition can range from slow evolution of oxygen gas to a vapor phase detonation of hydrogen peroxide vapors.

\section{INTRODUCTION}

Hydrogen peroxide is used at Rocky Flats for precipitation of plutonium from nitric acid solutions. Under certain conditions, hydrogen peroxide can undergo rapid decomposition, which can result in dangerously high pressures if the decomposition occurs in a confined space.

The peroxide precipitation system in one building was shut down for several months. Prior to resuming this operation, an evaluation of the procedures and equipment was conducted to determine whether any safety problems existed. One portion of this evaluation included reviews of the literature on hydrogen peroxide safety as well as previous safety incidents involving hydrogen peroxide in a Rocky Flats plutonium recovery building. The purpose of this report is to present a summary of information developed from the literature review.

\section{LITERATURE REVIEW}

Hydrogen peroxide is a clear, colorless liquid that is miscible with water in all proportions. Its molecular weight is 34.02 , and the density of the 35 wt \% solution used at Rocky Flats for precipitating plutonium peroxide is $1.128 \mathrm{~g} / \mathrm{cm}^{3}$ at $25^{\circ} \mathrm{C}$. The freezing point of $35 \mathrm{wt} \%$ hydrogen peroxide is $-33^{\circ} \mathrm{C}$, and the boiling point at $760 \mathrm{~mm} \mathrm{Hg}$ is $107.4^{\circ} \mathrm{C}$.

Hydrogen peroxide solutions in contact with the eyes can cause chemical burns, which can result in severe injury or even blindness. Contact with the skin can cause irritation, chemical burns, or thermal burns, depending on the concentration. Proper protective clothing must be worn even when handling the $35 \mathrm{wt} \%$ solutions.

Hydrogen peroxide decomposes as shown in Equation 1.

$$
2 \mathrm{H}_{2} \mathrm{O}_{2} \rightarrow 2 \mathrm{H}_{2} \mathrm{O}+\mathrm{O}_{2}+\text { HEAT }
$$

The decomposition products are water, oxygen, and heat $\left(22.72 \mathrm{kcal} / \mathrm{gmole}\right.$ of $\left.\mathrm{H}_{2} \mathrm{O}_{2}\right)$. This decomposition is normally slow at room temperature, but increases with temperature. The decomposition rate of hydrogen peroxide increases by a factor of two for each $10^{\circ} \mathrm{C}$ rise in temperature $^{1}$ and is approximately 200 times as fast at the boiling point as at room temperature. ${ }^{2}$ The rate of decomposition is also increased by addition of certain impurities to solutions of hydrogen peroxide or by contact of these solutions with insoluble catalytic agents. 
Homogeneous decomposition occurs when contaminants that catalyze the decomposition are present in aqueous solutions of hydrogen peroxide. Alkalies and strong acids, such as nitric acid, will catalyze the decomposition, as will dissolved salts of nickel, chromium, copper, iron, molybdenum, tungsten, and vanadium. Heterogeneous decomposition can occur when hydrogen peroxide solutions contact insoluble catalytic agents, such as silver, gold, platinum, palladium, and transition metals.

Some decomposition occurs when hydrogen peroxide is in contact with any surface. However, the decomposition rate varies greatly, depending on the nature and state of the surface. The decomposition rate of hydrogen peroxide in contact with silver is $10^{7}$ times faster than when in contact with polyethylene. ${ }^{3}$ Some decomposition occurs when hydrogen peroxide contacts Pyrex glass; the rate depends on the condition of the surface. ${ }^{4}$ If the concentration of hydrogen peroxide in the vapor phase exceeds 26 mole \%, the vapors can be exploded by a spark, contact with catalytically active materials, or contact with materials that are normally non-catalytic if surface temperature exceeds $150^{\circ} \mathrm{C}$. This situation normally occurs only when hydrogen peroxide concentration in the liquid phase exceeds $65 \mathrm{wt} \% .^{5}$

\section{PREVIOUS ROCKY FLATS INCIDENTS}

Reports describing two incidents attributed to decomposition of hydrogen peroxide were reviewed. Both occurred in the building referred to in this study. Both incidents involved approximately $30-\ell$ glass vessels with 1 -in.-dia vacuum/ vent lines. However, the vessel involved in the second incident also contained a 1-in.-dia pressure relief device.

The first incident occurred in 1957 during normal plutonium precipitation operations. Some difficultly had been experienced previously while precipitating plutonium from the same tank of feed solution. Foaming had been observed in the precipitation vessel during addition of the hydrogen peroxide solution. The operation was being conducted in two 6-in.-dia by 66-in., 26- $\ell$ glass vessels. These vessels were sealed and equipped with a cooling coil, mechanical agitator, and a 1in.-dia vacuum/vent line. Precipitation operations were being carried out in both vessels using plutonium feed solution containing approximately $3 \mathrm{~g} / \ell$ iron and lesser quantities of copper, chromium, and nickel. The vessels were cooled to $3{ }^{\circ} \mathrm{C}$ prior to starting the operation.

While adding a $50 \mathrm{wt} \%$ solution of hydrogen peroxide, foaming was observed in both vessels. Additional hydrogen peroxide was added until a plutonium peroxide precipitate was formed, and the solutions were then allowed to digest for $\mathbf{3 0}$ minutes. During the digestion period, foaming increased in severity until the solution in one vessel erupted through the agitator packing gland and a sudden increase in pressure, or explosion, occurred in the second vessel. The second vessel ruptured, and the front panel was blown from the glovebox.

The second incident occurred in 1980 during nonroutine operations. Hydrogen peroxide solution (35 wt \% $\mathrm{H}_{2} \mathrm{O}_{2}$ ) was being transferred from the supply tank in the chemical makeup area into the filtrate evaporator. The hydrogen peroxide in the supply tank was several months old. Destruction in the filtrate evaporator was (and still is) the method used to dispose of old hydrogen peroxide no longer suitable for production operations.

Maintenance operations were also being performed in the precipitation and filtrate evaporator gloveboxes, and steel tools from the maintenance operations were lying on the floor of the gloveboxes. Nitric acid from leaking equipment was on the glovebox floor. The acid contained approximately $4 \mathrm{~g} / \ell$ iron, $0.15 \mathrm{~g} / \ell$ copper, $0.4 \mathrm{~g} / \ell$ nickel, and various concentrations of other metallic impurities.

The hydrogen peroxide solution was being transferred from the supply line near the top of the glovebox to the filtrate receiver vessels, using a temporary connection made with Tygon tubing. When the valve in the supply line was opened, approximately 1 \& $35 \mathrm{wt} \%$ hydrogen peroxide 
solution leaked from the tubing connection onto the glovebox floor. A floor pickup wand attached to a 30- $\ell$ glass pickup vessel was on the glovebox floor in an area where leaking solution normally collected.

The floor pickup vessel contained six to eight liters of solution high in iron, copper, and nickel.

When the leaking peroxide solution collected in the area where the pickup wand was located, it was vacuumed into the pickup vessel.

The hydrogen peroxide reacted with the metallic impurities already present in the pickup vessel, and foaming occurred in the vessel. Within a few minutes, a stream of liquid was ejected from the one-inch pressure relief vent on top of the pickup vessel, and the glovebox system was pressurized. It is not clear from the incident report whether pressurization resulted from rapid decomposition of liquid hydrogen peroxide or detonation of hydrogen peroxide vapors. In either case, the reaction was sufficiently violent to cause the glovebox walls to flex outward and eject plutonium contamination into the room.

Several conclusions can be drawn from the review of these occurrences. First, both incidents were caused by hydrogen peroxide contacting solutions containing gram-per-liter quantities of iron and other impurities, which catalyze the decomposition. Second, even in vessels equipped with internal cooling coils, decomposition reaction may generate heat faster than it can be removed. Third, proper venting of vessels can reduce the severity of a hydrogen peroxide decomposition reaction, but venting will not prevent decomposition.

\section{HYDROGEN PEROXIDE DECOMPOSITION RATES}

Knowing the rate at which hydrogen peroxide decomposes is very important in predicting the probable consequences of a decomposition incident. If the decomposition rate is slow, the gaseous products from the decomposition reaction can be harmlessly vented from the reaction vessel.
TABLE 1. Effect of Nitric Acid Concentration on Hydrogen Peroxide Decomposition Reaction-Rate Constant $^{\mathrm{a}}$

\begin{tabular}{|c|c|}
\hline $\begin{array}{c}\mathrm{HNO}_{3} \text { Conc. } \\
(M)\end{array}$ & $\begin{array}{c}\text { Rate Constant } \\
\left(\mathrm{k} \times 10^{4} \mathrm{sec}^{-1}\right)\end{array}$ \\
\hline 1.7 & 0.144 \\
\hline 2.9 & 0.599 \\
\hline 4.1 & 2.460 \\
\hline
\end{tabular}

a. Solution: $93-99^{\circ} \mathrm{C}$

However, as these preceding incidents show, conditions can exist where the rate of gas evolution is greater than the capacity of the venting system. Predicting decomposition rates is complex, because the rate of decomposition depends on many factors, including temperature, pressure, and the type and concentration of decomposition catalyst.

Very little is available in the literature concerning decomposition rates for hydrogen peroxide under conditions encountered in Rocky Flats processing lines. However, some experimental work was conducted at Rocky Flats by Miner and Hagan. ${ }^{6}$ This work used $12 M$ (nominally 35 wt \%) hydrogen peroxide in various solutions.

The work was conducted at solution temperatures of 93 to $99^{\circ} \mathrm{C}$ by preparing solutions of hydrogen peroxide in various concentrations of nitric acid and with various concentrations of catalytic impurities. Solution samples were taken periodically and analyzed for hydrogen peroxide concentration, and these data were used to calculate decomposition reaction-rate constants. The authors stated that analysis of data from these experiments indicated that decomposition of hydrogen peroxide is a first-order reaction.

Data from this report on the effect of nitric acid concentration on the hydrogen peroxide decomposition reaction-rate constant are shown in Table 1. For a first-order reaction, a half-life period, $t_{1 / 2}$, can be calculated if the reaction-rate constant is known. ${ }^{7}$ The half-life period is the 
time required for half of the material initially present to decompose. It can be calculated using Equation 2.

$$
\mathrm{t}_{1 / 2}=0.693 / \mathrm{k}
$$

where $\mathrm{k}$ is the reaction-rate constant.

This equation was used to calculate half-life times for decomposition of hydrogen peroxide in nitric acid solutions, using reaction-rate constants from Table 1. The results of these calculations are given in Figure 1, which shows that the time for half of the hydrogen peroxide to decompose decreased from $48,000 \mathrm{sec}$ at $1.7 \mathrm{M} \mathrm{HNO}_{3}$ to $2,800 \mathrm{sec}$ at $4.1 M \mathrm{HNO}_{3}$.

Regression analyses were performed on the data in Table 1 to determine whether a good fit could be found. How well data fit a regression curve can be determined by calculating an $\mathrm{r}^{2}$ value for the curve. An $r^{2}$ of one indicates a perfect fit, and deviation from one indicates decreasing precision. Logarithmic, power, and exponential regression curves were generated for the data in Table 1 and an $r^{2}$ value of 0.9999932 was obtained for the exponential curve, indicating an almost perfect fit. The exponential curve generated using the reaction-rate constant data from Table 1 is shown in Figure 2. The experimental data were extrapolated using Equation 3 for an exponential curve, with $\mathrm{a}=0.0193293$ and $\mathrm{b}=1.1825430$.

$$
y=a e^{b x}
$$

(Equation 3)

Half-life times were calculated using the extrapolated reaction-rate constants. Results are given in Table 2, along with the experimental data and the extrapolated reaction-rate constants. As this table shows, the half-life time decreased to 91 sec for $7 \mathrm{MHNO}$, and to less than $1 \mathrm{sec}$ for $12 M \mathrm{HNO}_{3}$. There is always some risk involved in extrapolating experimental data, because the range over which a correlation is valid cannot be known without supporting experimental evidence. However, the extrapolated values in Table 2 indicate that decomposition of hydrogen peroxide becomes very rapid in high concentrations of nitric acid at $\sim 95^{\circ} \mathrm{C}$.
TABLE 2. Effect of Nitric Acid Concentration on Hydrogen Peroxide Decomposition Half-Life Time $^{\mathbf{a}}$

\begin{tabular}{|c|c|c|}
\hline $\begin{array}{c}\mathrm{HNO}_{3} \\
(M)\end{array}$ & $\begin{array}{c}\text { Rate Constant } \\
\left(\mathrm{k} \times 10^{4} \sec ^{-1}\right)\end{array}$ & $\begin{array}{c}\text { Half-life Time } \\
(\mathrm{sec})^{2}\end{array}$ \\
\hline 1.7 & 0.144 & $48,125.0$ \\
\hline 2.9 & 0.599 & $11,569.0$ \\
\hline 4.1 & 2.460 & $2,817.0$ \\
\hline 7.0 & $76.071^{\mathrm{b}}$ & 91.0 \\
\hline 8.0 & $248.194^{\mathrm{b}}$ & 28.0 \\
\hline 9.0 & $809.773^{\mathrm{b}}$ & 8.5 \\
\hline 10.0 & $2,642.014^{\mathrm{b}}$ & 2.62 \\
\hline 11.0 & $8,619.995^{\mathrm{b}}$ & 0.80 \\
\hline 12.0 & $28,124.119^{\mathrm{b}}$ & 0.25 \\
\hline
\end{tabular}

a. Solution: $93.99^{\circ} \mathrm{C}$

b. Extrapolated value

Miner and $\mathrm{Hagan}^{6}$ also included data for the effect of iron and copper on decomposition of hydrogen peroxide. These experiments were all conducted in $1.7 M \mathrm{HNO}_{3}, 3.4 M \mathrm{H}_{2} \mathrm{O}_{2}$ solutions. Decomposition half-life times were calculated using the experimental reaction-rate constant data for iron. These calculations showed that the time for half of the hydrogen peroxide to decompose decreased from $36,094 \mathrm{sec}$ for solutions containing $\mathbf{0 . 7 3}$ $\mathrm{mg} / \ell$ iron to $52 \mathrm{sec}$ for solutions containing 381 $\mathrm{mg} / \ell$. Figure 3 shows the experimental decomposition reaction-rate constants and calculated decomposition half-life times for various concentrations of $\mathrm{Fe}^{+3}$. The first three decomposition half-life data points were omitted in Figure 3 to show the data for the higher iron concentrations more clearly.

Regression analyses performed on the iron reaction-rate constant data indicated that the best fit for this data was obtained with a linear regression line. The $r^{2}$ valve for the linear regression was 0.9992298 , which indicates a very good fit. The data for iron was extrapolated using the formula for a linear regression line $(y=a+$ $b x)$, with $a=-0.297143$ and $b=0.3533848$. 
TABLE 3. Effect of Fe(III) Concentration on Hydrogen Peroxide Decomposition Reaction-Rate Constant and Half-Life Time ${ }^{\mathrm{a}}$

\begin{tabular}{||c|c|c|}
\hline $\begin{array}{c}\text { Fe(III) Conc } \\
(\mathrm{mg} / \ell)\end{array}$ & $\begin{array}{c}\text { Rate Constant } \\
\left(\mathrm{k} \times 10^{4} \mathrm{sec}^{-1}\right)\end{array}$ & $\begin{array}{c}\text { Half-life Time } \\
(\mathrm{sec})\end{array}$ \\
\hline 0.73 & 0.192 & 36,094 \\
\hline 1.45 & 0.201 & 34,478 \\
\hline 7.30 & 1.260 & 5,500 \\
\hline 38.00 & 12.200 & 568 \\
\hline 95.00 & 33.600 & 206 \\
\hline 190.00 & 69.600 & 100 \\
\hline 381.00 & 133.000 & 52 \\
\hline 500.00 & $176.000^{\mathrm{b}}$ & 40 \\
\hline 750.00 & $265.000^{\mathrm{b}}$ & 26 \\
\hline 1000.00 & $353.000^{\mathrm{b}}$ & 20 \\
\hline
\end{tabular}

a. Solution: $1.7 \mathrm{M} \mathrm{HNO}, 3.4 \mathrm{M} \mathrm{H}_{2} \mathrm{O}_{2}\left(93.99^{\circ} \mathrm{C}\right)$

b. Extrapolated value

TABLE 4. Effect of $\mathrm{Cu}$ (II) Concentration on Hydrogen Peroxide Decomposition ReactionRate Constant and Half-Life Time ${ }^{\mathrm{a}}$

\begin{tabular}{|c|c|c|}
\hline $\begin{array}{c}\text { Cu(II) Conc. } \\
(\mathrm{mg} / \ell)\end{array}$ & $\begin{array}{c}\text { Rate Constant } \\
\left(\mathrm{k} \times 10^{4} \mathrm{sec}^{-1}\right)\end{array}$ & $\begin{array}{c}\text { Half-life Time } \\
(\mathrm{sec})\end{array}$ \\
\hline 0.83 & 2.16 & 3208 \\
\hline 1.66 & 2.71 & 2557 \\
\hline 8.28 & 4.58 & 1513 \\
\hline 43.20 & 8.04 & 862 \\
\hline 108.00 & 9.29 & 746 \\
\hline 216.00 & 11.70 & 592 \\
\hline 433.00 & 13.90 & 499 \\
\hline 750.00 & $17.09^{\mathrm{b}}$ & 406 \\
\hline 1000.00 & $18.62^{\mathrm{b}}$ & 372 \\
\hline
\end{tabular}

a. Solution: $1.7 \mathrm{MHNO}_{3}, 3.4 \mathrm{M} \mathrm{H}_{2} \mathrm{O}_{2}\left(93.99^{\circ} \mathrm{C}\right)$

b. Extrapolated value
Figure 4 shows the linear regression line for both the experimental and extrapolated decomposition rate constant data for iron. The calculated decomposition half-life data are shown in Figure 5 with the first three data points again omitted for clarity. All of the reaction-rate constant and half-life time data for iron are given in Table 3. Note that the time required for half of the hydrogen peroxide to decompose decreased to $20 \mathrm{sec}$ for solutions containing $1 \mathrm{~g} / \ell \mathrm{Fe}^{+3}$.

Analyses similar to those performed for the nitric acid and iron data were conducted for copper. The experimental reaction-rate constant data and the calculated decomposition half-life times for copper are shown in Figure 6. Regression analyses indicated that a power regression gave the best fit $\left(r^{2}=0.9953239\right)$, although the fit was not quite as good as those obtained for the nitric acid and iron data.

Extrapolation of the reaction-rate constant data for copper was performed using the formula for a power regression curve, $y=a x^{b}$, with $a=2.3640506$ and $b=0.2987670$. The experimental and extrapolated values for the reaction-rate constants are plotted in Figure 7 , with a logarithmic scale used for the $\mathrm{x}$ axis. Table 4 contains the reaction-rate constant data and the calculated half-life times for copper. This table shows that low concentrations of copper have a greater effect on the decomposition of hydrogen peroxide than was the case for iron. However, increased concentration of copper does not accelerate the decomposition of hydrogen peroxide as much as increased concentration of iron.

In addition to the data on individual effects of nitric acid, iron, and copper on decomposition of hydrogen peroxide, the report by Miner and Hagan contained some data on the effects of combinations of these catalysts. The effect of small quantities of copper on the decomposition rate caused by iron is given in Table 5. The addition of copper has a major initial effect on the decomposition rate; but as the iron concentration increases, the effect of the copper decreases. 
TABLE 5. Combined Effect of $\mathrm{Fe}$ (III) and $\mathrm{Cu}$ (II) on Hydrogen Peroxide Decomposition Reaction-Rate Constant and Half-Life Time ${ }^{\mathrm{a}}$

\begin{tabular}{|c|c|c|c|c||}
\hline & \multicolumn{2}{|c|}{ NO Cu(II) } & \multicolumn{2}{c|}{$0.83 \mathrm{mg} / \ell \mathrm{Cu}(\mathrm{II})$} \\
\hline $\begin{array}{c}\text { Fe(III) Conc. } \\
(\mathrm{mg} / \ell)\end{array}$ & $\begin{array}{c}k \times 10^{4} \\
(\mathrm{sec})\end{array}$ & $\begin{array}{c}\text { Half-life } \\
\text { Time (sec) }\end{array}$ & $\begin{array}{c}k \times 10^{4} \\
\left(\mathrm{sec}^{-1}\right)\end{array}$ & $\begin{array}{c}\text { Half-life } \\
\text { Time (sec) }\end{array}$ \\
\hline 0 & 0.144 & 48,125 & 2.16 & 3208 \\
\hline 38 & 12.200 & 568 & 21.20 & 327 \\
\hline 95 & 33.600 & 206 & 38.80 & 179 \\
\hline 190 & 69.600 & 100 & 66.20 & 105 \\
\hline 381 & 133.000 & 52 & 147.00 & 47 \\
\hline
\end{tabular}

a. Solution: $1.7 \mathrm{M} \mathrm{HNO}_{3}, 3.4 \mathrm{M} \mathrm{H}_{2} \mathrm{O}_{2}\left(93.99{ }^{\circ} \mathrm{C}\right)$

TABLE 6. Effect of $\mathrm{HNO}_{3}$ Concentration on the $\mathrm{Cu}(\mathrm{II})$ and $\mathrm{CU}(\mathrm{II})$ Plus Fe(III) Catalyzed Decomposition Rate of Hydrogen Peroxide ${ }^{\mathrm{a}}$

\begin{tabular}{||c|c|c|c||}
\hline & \multicolumn{3}{|c|}{ Half-life Time (sec) } \\
\hline $\begin{array}{c}\mathrm{HNO}_{3} \text { Conc. } \\
(M)\end{array}$ & NO Cu or Fe & $1.7 \mathrm{mg} / \ell \mathrm{Cu}(\mathrm{II})$ & $\begin{array}{c}1.7 \mathrm{mg} / \ell \mathrm{Cu}(\mathrm{II}) \text { and } \\
38 \mathrm{mg} / \ell \mathrm{Fe}(\mathrm{III})\end{array}$ \\
\hline 1.7 & 48,125 & 2557 & 328 \\
\hline 2.9 & 11,569 & 1006 & 318 \\
\hline 4.1 & 2,817 & 428 & 235 \\
\hline
\end{tabular}

a. Solution: $3.4 \mathrm{M} \mathrm{H}_{2} \mathrm{O}_{2}\left(93-99^{\circ} \mathrm{C}\right)$

Data on the effect of adding small quantities of copper and copper plus iron on the decomposition of hydrogen peroxide in nitric acid solutions are given in Table 6 and Figure 8. Adding small quantities $(1.7 \mathrm{mg} / \ell)$ of copper greatly increases the decomposition rate in nitric acid, and adding small quantities of both iron and copper results in a further increase.

Regression analyses performed on the reaction-rate constant data for small quantities of copper and copper plus iron yielded a good correlation for the data from small quantities of copper, but an acceptable correlation could not be obtained for the data from small quantities of copper plus iron.
The regression curves providing the best fit are shown in Figure 9. An exponential regression provided the best correlation for both the copper and copper-plus-iron data. However, the $r^{2}$ value for the copper-plus-iron data was only 0.8222826 , and no attempt was made to extrapolate these data. The $\mathrm{r}^{2}$ value obtained for copper-only data was 0.9993631 , which indicates a very good correlation.

The experimental and extrapolated reaction-rate constants for decomposition of hydrogen peroxide in nitric acid solutions containing $1.7 \mathrm{mg} / \ell$ copper are shown in Table 7, along with the same data $f$ nitric acid solutions without copper. The 
RFP-4599

TABLE 7. Comparison of Hydrogen Peroxide Decomposition Rate in Nitric Acid Solutions with and without Copper

\begin{tabular}{||c|c|c|c|c||}
\hline & \multicolumn{2}{|c|}{$\mathrm{NOCu}$ (II) } & \multicolumn{2}{c||}{$1.7 \mathrm{mg} / \mathrm{l}$ Cu(II) } \\
\hline $\begin{array}{c}\text { HNO }{ }^{3} \mathrm{Conc} \\
(M)\end{array}$ & $\begin{array}{c}\mathrm{k} \times 10^{4} \\
\left(\mathrm{sec}^{-1}\right)\end{array}$ & $\begin{array}{c}\text { Half-life Time } \\
(\mathrm{sec})\end{array}$ & $\begin{array}{c}\mathrm{k} \times 10^{4} \\
\left(\mathrm{sec}^{-1}\right)\end{array}$ & $\begin{array}{c}\text { Half-life Time } \\
(\mathrm{sec})\end{array}$ \\
\hline 1.7 & 0.144 & 48,125 & 2.710 & 2557 \\
\hline 2.9 & 0.599 & 11,569 & 6.890 & 1006 \\
\hline 4.1 & 2.460 & 2,817 & 16.200 & 428 \\
\hline 7.0 & $76.071^{\mathrm{b}}$ & 91 & $142.397^{\mathrm{b}}$ & 49 \\
\hline 8.0 & $248.194^{\mathrm{b}}$ & 28 & $299.958^{\mathrm{b}}$ & 23 \\
\hline 9.0 & $809.773^{\mathrm{b}}$ & 8.5 & $631.860^{\mathrm{b}}$ & 11 \\
\hline 10.0 & $2,642.014^{\mathrm{b}}$ & 2.6 & $1,331.012^{\mathrm{b}}$ & 5.2 \\
\hline 11.0 & $8,619.995^{\mathrm{b}}$ & 0.80 & $2,803.771^{\mathrm{b}}$ & 2.5 \\
\hline 12.0 & $28,124.119^{\mathrm{b}}$ & 0.25 & $5,906.133^{\mathrm{b}}$ & 1.2 \\
\hline
\end{tabular}

a. Solution: $1.7 \mathrm{MHNO}_{3}, 3.4 \mathrm{M} \mathrm{H}_{2} \mathrm{O}_{2}\left(93-99^{\circ} \mathrm{C}\right)$

b. Extrapolated value

calculated decomposition half-life times for both sets of reaction-rate constants are also given in Table 7. Extrapolation of the data for both nitric acid without copper and nitric acid with copper yields similar results. Data from both extrapolations show that the decomposition rate of hydrogen peroxide becomes very rapid in concentrated nitric acid solutions, and this tends to confirm the validity of the extrapolated data.

The data developed by Miner and Hagan serve to quantify the information available from other literature sources concerning the catalytic decomposition of hydrogen peroxide. Information from several literature sources indicated that nitric acid, iron, and copper would catalyze the decomposition of hydrogen peroxide. The work by Miner and Hagan shows that concentrations of nitric acid, iron, and copper considered safe in the plutonium peroxide precipitation process can cause rapid decomposition of hydrogen peroxide if the solution temperature is increased to the boiling point. For example, the safe upper limit for iron in feed solutions for the plutonium peroxide precipitation process is currently considered to be $1000 \mathrm{mg} / \ell$. However, the decomposition half-life for hydrogen peroxide in a $1.7 \mathrm{M} \mathrm{HNO}_{3}, 3.4 \mathrm{M}$ $\mathrm{H}_{2} \mathrm{O}_{2}$ solution containing $1000 \mathrm{mg} / \mathrm{l}$ iron is only $20 \mathrm{sec}$ at $\sim 95^{\circ} \mathrm{C}$. The decomposition half-life would be expected to decrease as the nitric acid concentration increased to $4 M$, which is the nitric acid concentration used for feed solutions to the plutonium peroxide precipitation process.

\section{CONCLUSIONS}

The information in this report confirms what has been known for many years concerning conditions required for safe operation of the plutonium peroxide precipitation process at Rocky Flats.

- Solutions containing hydrogen peroxide must be maintained at low temperatures.

- Iron, copper, and other impurities that catalyze the decomposition of hydrogen peroxide must be maintained at low concentrations. 


\section{RFP-4599}

- Process vessels that contain or could contain hydrogen peroxide solutions must be properly vented.

However, conditions can occur in the processing lines that result in unacceptable consequences, as the previous incidents demonstrate. Proper engineering of process equipment to limit possible conditions causing rapid decomposition of hydrogen peroxide in a confined space is very important. However, training personnel who handle hydrogen peroxide and establishing precautions for safe operation are even more important. Using well-trained operating personnel is the most important factor if these operations are to be conducted safely.

\section{REFERENCES}

1. W. C. Schumb, C. N. Satterfield, and R. L. Wentworth, Hydrogen Peroxide, p 525,
Reinhold Publishing Corporation, New York, NY, 1955.

2. "Hydrogen Peroxide Safety and Handling," Report Number P 1.3.2, Interox America, Houston, TX.

3. "Hydrogen Peroxide," Report Number P 1.1.1, Interox America, Houston, TX.

4. Reference 1, pp 447-458.

5. Reference 1, pp 179-181.

6. F. J. Miner and P. G. Hagan, "Rate of Hydrogen Peroxide Decomposition in Nitric Acid Solutions," Ind. Eng. Chem., Process Des. Develop., 11, p 547, 1972.

7. F. Daniels and R. A. Alberty, Physical Chemistry, pp 321-322, John Wiley and Sons, Inc., New York, NY, 1955. 


\section{ILLUSTRATIONS}

\section{FIGURES 1 THROUGH 9}

FIGURE 1. Time Required to Decompose

One-Half of Initial Hydrogen Peroxide



FIGURE 2. Effect of $\mathrm{HNO}_{3}$ Concentration on $\mathrm{H}_{2} \mathrm{O}_{2}$ Decomposition Rate Constant



Decomposition: $95^{\circ} \mathrm{C}$ 
FIGURE 3. Effect of $\mathrm{Fe}$ (III) Concentration on $\mathrm{H}_{2} \mathrm{O}_{2}$ Decomposition



Solution: $1.7 \mathrm{MHNO}_{3}, 3.4 \mathrm{MH}_{2} \mathrm{O}_{2}\left(95^{\circ} \mathrm{C}\right)$

Decomposition Half-Life = Time Required to Decompose Half of Initial $\mathrm{H}_{2} \mathrm{O}_{2}$

FIGURE 4. Effect of $\mathrm{Fe}(\mathrm{III})$ Concentration of $\mathrm{H}_{2} \mathrm{O}_{2}$ Decomposition Rate Constant

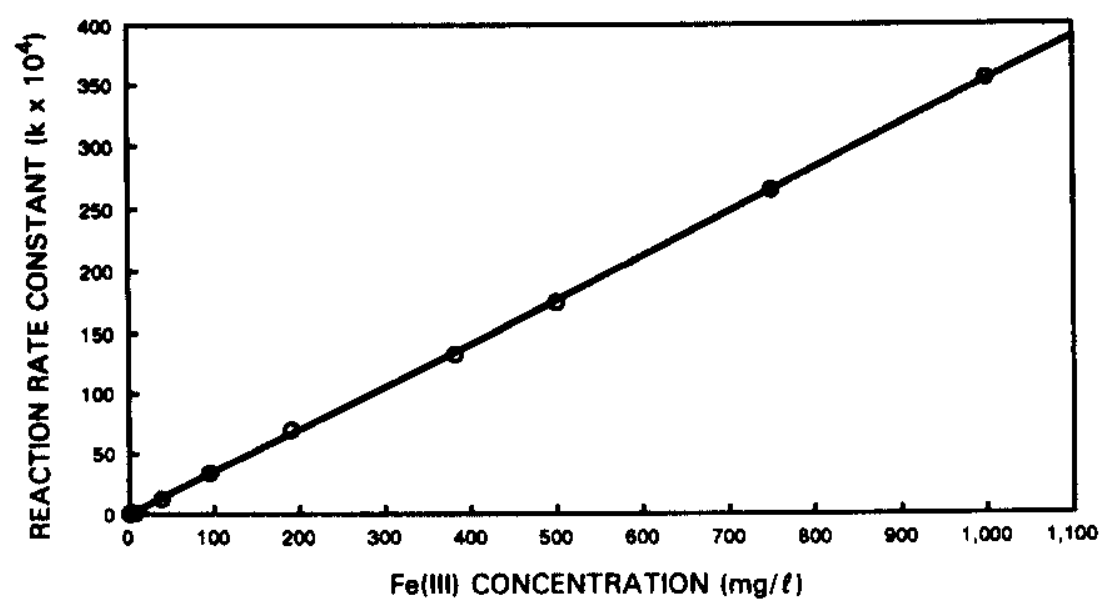

Solution: $1.7 \mathrm{MHNO}_{3}, 3.4 \mathrm{MH}_{2} \mathrm{O}_{2}\left(95^{\circ} \mathrm{C}\right)$ 
FIGURE 5. Effect of $\mathrm{Fe}$ (III) Concentration on $\mathrm{H}_{2} \mathrm{O}_{2}$ Decomposition Half-Life



Solution: $1.7 \mathrm{MHNO}_{3}, 3.4 \mathrm{MH}_{2} \mathrm{O}_{2}\left(95^{\circ} \mathrm{C}\right)$

FIGURE 6. Effect of $\mathrm{Cu}(\mathrm{II})$ Concentration on $\mathrm{H}_{2} \mathrm{O}_{2}$ Decomposition Rate



Solution: $1.7 \mathrm{MHNO}_{3}, 3.4 \mathrm{MH}_{2} \mathrm{O}_{2}\left(95^{\circ} \mathrm{C}\right)$

Decomposition Half-Life = Time Required to Decompose Half of Initial $\mathrm{H}_{2} \mathrm{O}_{2}$ 
FIGURE 7. Power Regression Curve for Effect of Cu(II) Concentration on $\mathrm{H}_{2} \mathrm{O}_{2}$ Decomposition Rate Constant

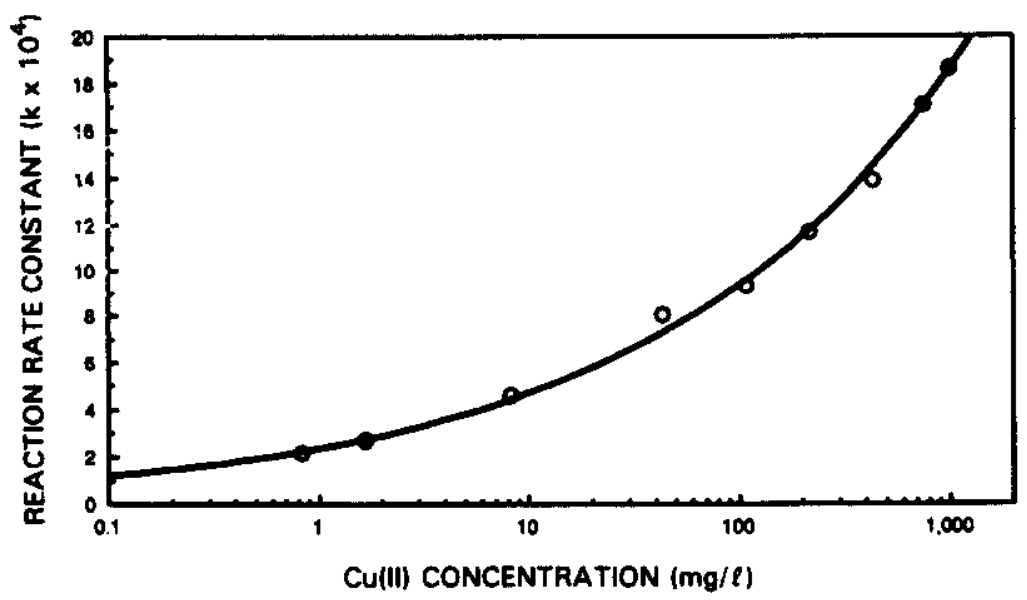

Solution: $1.7 \mathrm{MHNO}_{3}, 3.4 \mathrm{MH}_{2} \mathrm{O}_{2}\left(95^{\circ} \mathrm{C}\right)$

FIGURE 8. Effect of $\mathrm{HNO}_{3}$ Concentration on the $\mathrm{Cu}$ (II) and Cu(II) Plus Fe(III) Catalyzed Decomposition of Hydrogen Peroxide



$1.7 \mathrm{mg} / / \mathrm{Cu}$

$1.7 \mathrm{mg} / \ell \mathrm{Cu}+38 \mathrm{mg} / \ell \mathrm{Fe}$

- $0-$ -

Solution: $3.4 \mathrm{M} \mathrm{H}_{2} \mathrm{O}_{2}\left(95^{\circ} \mathrm{C}\right)$ 
FIGURE 9. Reaction-Rate Constant for $\mathrm{Cu}$ (II) and $\mathrm{Cu}$ (II) Plus Fe(III) Catalyzed Decomposition of Hydrogen Peroxide

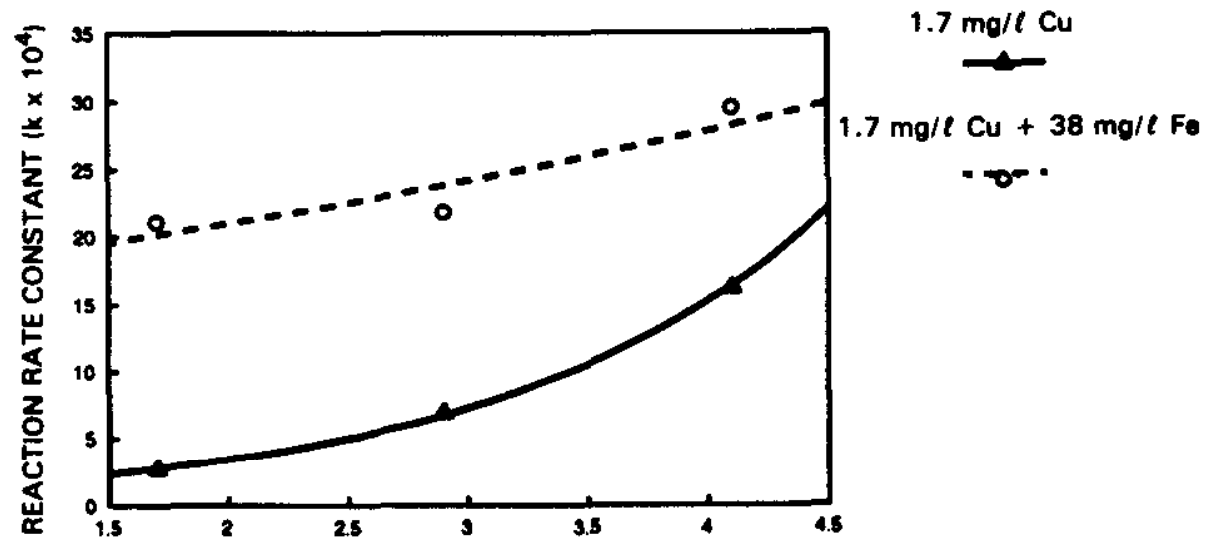

Solution: $3.4 \mathrm{MH}_{2} \mathrm{O}_{2}\left(95^{\circ} \mathrm{Cl}\right.$ 
RFP-4599 